\title{
En fourers oplevelser i 1850
}

\section{Uddrag af en fynsk jægers dagbog under treảrskrigen}

(Meddelt ved M. Vesterdal)

(FORTSAT)

Fra Isted til krigens afslutning.

Den danske hærs tab under slaget ved Isted var, når den foregående dags kampe medregnes, ialt godt 3600 mand, hvoraf ca. 850 faldne. På fjendens side var tabene omkring 2800, hvoraf ca. 1000 usårede fanger.

Som det er almindelig bekendt, blev den danske sejr ikke af afgørende betydning. Det havde været muligt at tilføje oprørshæren et tilintetgørende nederlag, der kunne have medført krigens endelige afslutning. I stedet var oprørerne blot svækket, og da politiske hensyn tilmed medførte en begrænsning $\mathrm{i}$ den danske overkommandos operationsfrihed, trak krigen stadig $i$ langdrag.

På dansk side stod hærens hovedstyrke i og om Slesvig, og man indskrænkede sig til en forsvarsmæssig optræden ved $\mathrm{Da}-$ nevirkestillingen, der forstærkedes ved forskansningsanlæg.

For 3. reservejægerkorps fulgte derfor en næsten regelbundet periode afvekslende mellem forposttjeneste og kantonnement i Slesvig by.

Forposttjenesten var ret anstrengende og enkelte alarmeringer fandt også sted under hvileperioderne i Slesvig.

Om denne periode skrev Morten i september således til sine forældre: „Her have I da et ordentligt langt Brev fra mig, nemlig 16 af mine sidste Dagbøger. ${ }^{1}$ ) Jeg har igaar og idag gjennem-

1) Dagbøgerne førtes i småhefter, der sendtes hjem, når lejlighed gaves. Disse optegnelser tjente $i$ det store og hele tillige som breve til hjemmet, hvorved tonen måske har fået præg af at skulle tjene til fælles læsning i det pietistiske hjem. 
seet dem. Med de første er jeg fornøiet, derimod har jeg ingenlunde været heldig med de sidste. Jeg kan tydelig see, at jeg er altfor ofte blevet forstyrret, naar jeg engang imellem har sat mig hen for at optegne Adskilligt om det, jeg har oplevet. Det er langtfra, som jeg vilde have skrevet det, om der havde været bedre Roelighed. Jeg seer at flere Ting er skrevne 2 Gange. Dog det gjør jo ikke noget. Jeg skriver kun .ligefrem mine Tanker om Et og Andet og vil lade det staae, som det er.

Gid disse Linier maae træffe Eder med Sundhed og Helsen.

Som ovenfor sagt er det simpelt, men I vil dog faae et Begreb om hvad jeg færdes i hver Dag.I vil see, hvorledes jeg har havt nogle mærkelige Dage, da jeg forlod Als efter at have ligget stadigt i $15^{1 / 2}$ Maaned og marscherte herop ad Slesvig Land igjennem Flensborg osv. Hvorledes jeg den 25. Juli har været Vidne til det store Slag ved Isted. Samme er mere udførlig beskrevet end jeg plejer van, og dog er det kun lidt.

I vil ogsaa see meget om Opholdet her i Slesvig, der burde have været mere fuldstændigt. Her kunde have været skrevet meget mere, thi naar man blot gaaer paa Gaden i Frederiksberg, møder man strax noget Mærkværdigt. Her bevæger sig et næsten uendeligt Antal Vogne af alle Slags: Ammunitionsvogne, Bøndervogne, Proviantvogne osv. Soldater af den danske Armees fleste Batailloner gaae op og ned ad Gaden, og til enhver Tid seer man et Compagnie have Appel.

Især om Morgenen er det pænt at see alle de her cantonnerende stille til Appell, der i de sidste Dage er forlænget til 3 Timer.

I see, at vi fløtte hver 4de Dag, da er her isærdeleshed et stort Røre. De indkommende Batailloner have gjerne fuld $\mathrm{Mu}-$ sik, hvilket er pænt at høre.

I faae ogsaa at see lidt om vor Forposttjeneste, saavidt som jeg har været med.

Jeg kunde ønske, at I havde seet, hvad der er lavet syd for Slesvig, hvorledes Markerne ere næsten opfyldte af Hytter og 
Barakker. Skandser ere opførte overalt, Gjerder og Hegn sløifede over $1 / 2$ Fjerdingvei udenfor Dannevirke. Sæden er i mange Marker aldeles nedtraadt, der i det Sted ere som et Logulv. Jeg onskede ogsaa, at I saae eller vare nærværende en Nat paa Forposttjeneste og see, hvorledes det gaaer til med Patrouillering osv. Dog det var jo ikke godt, at I saae det. I maae være glade ved, at I midt $i$ det venlige Fyn kan røgte Eders fredelige Gjerning.

Jeg har ogsaa fortalt Eder lidt om de Sammenstød, der næsten hver Dag i de 5 sidste Uger har været ved Forposterne - en og anden er stadig væk blevet saaret, men hidtil har Compagniet været heldig, og skjøndt enkelte Afdelinger af samme flere Gange har været i stor Fare, saa ere de dog hvergang slupne godt derfra.

Slesvigs Beboere ere endnu overhovedet lige tydsksindede, og de vente med Længsel, at den tydske Armee skal komme og jage os bort igjen. Bagved os, i Nordslesvig, ordnes Forholdene mere og mere, og den lovlige Orden synes der at vende tilbage, men naar det her bliver ordnet, er ikke godt at vide. Vi have alle det faste Haab, at vi ikke oftere skulle gaae tilbage, og saa vil med Tiden det ogsaa nok blive ordnet i Sydslesvig. Hvad derimod Holsteen angaaer, da staaer det til at forsøge, og vi vil siden faae at see, om vi komme der. Jeg tror det næsten.

Det kan ikke nægtes, at de Ungdomsønsker, jeg havde imedens jeg var hjemme, om at komme ud for, at see mig om ere for en Deel blevne opfyldte. I 21/2 Aar har jeg nu været fjernet fra Hjemmet, og det er tilvisse ikke lidt, jeg har seet, hørt og erfaret. Først, om Gud vil, at jeg engang maae komme til Eder igjen, vil det blive underligt at tænke tilbage paa disse Aar, da den slesvigske Krig førtes. Jeg fortryder ingenlunde, at jeg besluttede at gaae med; det var jo min Pligt at følge min Konges Ordre, og hidtil er det jo gaaet godt. Jeg har været Jykkelig hele Tiden i min Stilling som Soldat, hvilket jeg næst Gud maae 
takke min Capitain for, der har baaret en særdeles Godhed for mig. Kunde vi nu snart have faaet Fred i Landet igjen, og vi kunde samles i vor lille Familiekreds, da vil Glæden blive stor. Dog i Herrens Navn, jeg skal jo blive til Enden. Naar den kommer er skjult. - Idstedslaget var vist ikke det sidste endnu; men Gud give, om der mere skal kjæmpes, at vi maatte seire over vore Fjender, Oprørerne, som vi hidtil have gjort."

Dagbogen fortsætter nu således:

„Frederiksberg, Torsdagen den 12. Septbr. 1850.

Som jeg idag sad her paa vort Værelse, Kl. var vel 3, hører jeg nogle af Soldaterne nede i Gaarden raabe til hinanden, at de strax skulde møde paa Allarmpladsen. Jeg troede, at nu var Alting da roligt for idag, da det var allerede hen paa Eftermiddagen og blev derfor meget overrasket. Jeg gik ned og saae da Soldaterne ile til deres Quarterer for at faae deres Tøi, og efter et Øiebliks Forløb stod de alle opstillede her i Gaden. Ordonnantser kom i en Fart.

Det hed, at der var haard Fægtning ved Eckernførde, som jeg snart fik at see var Sandhed. Nede i en Have, hvorfra man har en god Udsigt, kunde jeg see Kampen paa begge Linier, men endnu bedre, da jeg fik fat i en god Kikkert og kom op i et hoit Huus.

$\mathrm{Nu}$ gik jeg ind at pakke sammen for at være beredt til at følge min Capitains Ordre, naar noget kom paa, nemlig at gaae ud til Krudtkarren, men vilde dog blive at see noget Nærmere.

Der kom nu ingen anden Ordre, og Kampen lod ikke til at komme nærmere herind, men vedblev at være paa vores venstre Fløi. Jeg troede da, der var ingen Fare ved at gaae ud til Hyhner-Häuser et Ærinde, som jeg fik Ordre paa igaar.

Det blev nu henimod Aften.

Da jeg kom op paa Hesterberg paa et høit Sted, kunde jeg endnu tydeligere see over Slien efter den Egn, hvor Fægtningen stod. 
De sloges endnu rask. Granaterne sprang i Luften og Ilden saaes ud af Kanonernes Munding. En uhyre Mængde Mennesker stod og saae til, hvad Udfald det vilde faae. Efter der at have staaet lidt, gik jeg tilligemed Falling op paa Vognpladsen. Det var en sjelden skjøn Aften; men som saamange har været, var denne ogsaa bedrøvelig. Med Opmærksomhed vedbleve vi at see over ad Eckernførde til, og skjøndt det var nu Aften, kjæmpedes endda, og dumpe Kanondrøn hørtes bestandig, og særdeles tydeligt saaes Glimtende af baade Kanoner og Geværer.

Omtrent $\mathrm{Kl} .7^{1 / 2}$ saaes der at være tændt Ild an, og strax derpaa antændtes 3 andre Boliger, saa der brændte 4 Steder paa eengang, der vare omtrent lige langt fra hverandre. Efter et Quarters Forløb tændtes ogsaa Ild et 5te Sted, det saae ud, som det var i nogle sammenliggende Boliger, thi Ilden løb som med Lynets Hastighed rundtomkring. Flammerne stege iveiret, og det var som man saae et Ildhav. Jeg har i mine Dage aldrig seet et saadant Syn, der formedelst Aftenen var dobbelt rædsomt at see. Vi antog, at det maatte være en heel Bye, man hørte Bønderne fra den Egn, som ere i Agt ved Arméen sige den ene til den anden, at det var der og der, men bestemt kunde vi ikke faae det at vide. Allersidst saaes endnu længere tilhøire nok en Ildebrand, saa vi med rette studsede over alt dette, over al den Ødelæggelse, vi skulde være Vidne til. Hvilken Aften jeg har oplevet kan ikke beskrives. Med bevæget Sind og Tanke gik jeg tilbage igjen.

Et næsten uendeligt Rumlen af Vogne hørtes paa Slesvigs Gader og paa Veien til Vognpladsen og Vognparken. Maanen skjinnede blankt og Lygterne vare tændte i Byen. I Skyen saaes rødlige Skjær derudefra. Jeg glemmer aldrig denne Aften. Endnu efter at jeg er kommet hjem sees en forskrækkelig Ildebrand ud over Haddeby Noer. O hvilken Nød og Elendighed for saamange Mennesker, der maae savne Huus og Hjem mod Vinteren. Hvilke haarde Tugtelser gaae ikke over vort lille 
Land - og maaskee er endnu mere tilbage. Jeg antager, at det ikke vil vare mange Dage, før Fjenden rykker paa os. Ja jeg er spændt paa Morgenen, eftersom der er Grund til at troe, at dette idag kun er en Begyndelse. Gud give dog, at vi maatte beholde Seier. Haardt vil det blive, thi Fjenden vover alt, men naar kun Gud er med os, saa vil hans Værk lykkes fremfor Fjendens.

Feltvagt paa Ober Selk Mark, den 14de Septbr. 1850.

Corpset stillede Kl. 4 og forblev staaende til $\mathrm{Kl}$. 5 , da vi afmarcherte for at afløse Forposterne. 4de Compagnie afløste 13de Batl.s 1ste Compagnie, der havde yderste Forpost. Vi have idag en meget behagelig Vagt. Det har været et udmærket godt Veir, og vi ligge paa et ret rart Sted.

Uden for vores Vedetter ${ }^{2}$ ) ere udsendte nogle Commandoer paa adskillige Steder, der forblive staaende og ere ligesom til at markere Fjendens Fremrykning, da de strax have at trække sig tilbage. Fra denne Feltvagt ${ }^{3}$ ) er saaledes udsendt nogle Mand til Lottorf og "det rode Huus" til hvilket sidste Sted, der ligger paa Breckendorf-Veien, tillige er 1 Officeer. Disse Commandoer ere udsatte for den største Fare, især kunde det nemt skee, at de kunde blive omgaaede og tagne tilfange, og de maae være vel paa Deres Post.

Vi ere ikke blevne allarmerede idag med Undtagelse af at disse Commandoer i Eftermiddag tilvenstre mod Geltorf have vexlet nogle enkelte Skud med en fjendtlig Patrouille, som der siges at være kommet fra Breckendorf.

Sidste [Gang] at Corpset var paa Forpost og 2det Compagnie var her paa Feltvagt, blev en dobbelt Post en Kalv vaer, som forekom dem som en Tydsker. Den blev raabt an, men da den ikke svarte med saa meget som et Brøl, blev den skudt, og Po-

2) De forreste poster på 2-3 mand anbragt, så øjenforbindelse haves.

3) Bag vedetterne står feltvagten, hvorfra poster og patrouiller udsendes. 
sten gik lidt tilbage. Om Morgenen laae Kalven og var død. 13de Batl. har igaar spist den.

Frederiksberg, den 15. September 1850.

Skjøndt Veiret var efter Aarstiden overmaade godt, var det dog koldt, og nu da Natten allerede er lang, var det lidt drøit. Capitainen gav Folkene Lov at lægge Tornistrene her paa Feltvagten, saa de havde det bedre end dem i Lottorf og ved „det røde Huus", der fra iaftes uafladelig har staaet med dem paa, og strax efter Afløsningen maatte de marschere ind til Byen, saa de havde dem paa i 15 Timer. Her udgik Patrouiller hver Time hele Kjæden rundt, og det øvrige Mandskab stod Post den halve Tid af Natten. Iaftes $\mathrm{Kl}$. 10 bleve vi allarmerede ved Skud i Retningen af Geltorf, der vedblev saa smaat nok omtrent en Times Tid. Fjenden forsøgte at omgaae et af 3 . Compagnie i denne Bye staaende Commando, der heldigviis ikke blev til noget.

Mærkelig nok var netop en rigtig Skryder, en Overjæger O..., ved 3. Comp. derude. Han havde iagttaget alle de Forsigtighedsregler, som han i sin formeentlige Viisdom kunde finde for at sikre sig.

Han lode alle Bønderne i Byen, Skolelæreren med, stille til Appel for sig og befalede dem at slaae alle deres Hunde løse for at de ikke skulde staae og knurre i Gaardene og ikke dermed nok. Han satte disse tydsksindede Bønder til at staae Post, og hvis de ei meldte ham, naar Fjenden kom, stak han Byen i Brand, Noget som han slet ikke havde Ordre paa.

Da nu Tydskerne kom, var han ikke nær den Karl, da løb han nok saa behændig fra Gettorf, ja der siges endog, at han græd.

Imorges var der atter Sammenstød ved Krop, men der faldt kun enkelte Skud. Vi bleve afløste af 3die Liniebataillons 3. Compagnie og marscherte derpaa herind til Byen til vores gamle Quarterer. 
Frederiksberg, den 16. September 1850.

Idag skulde Nogle af de Faldne i Slaget ved Midsunde den 12 te dennes begraves. Jeg syntes ogsaa at ville see dette og begav mig til Domkirken, hvor Ligene vare henlagte strax efter Affairen. Jeg hørte ikke ret meget af den Tale, som Feltpræst Dahlerup holdt, da jeg kom lidt seent. Kisterne, 8 i Tallet, gjemmende Støvet af Capitain Schou af Artilleriet, Capitain Kuhle af 3die Reservebataillon, 1 Sergeant af samme og 5 menige, vare hensatte $i$ Choret.

Efterat Talen var tilende bleve Kisterne [ført] fra Domkirken til Michaeli Kirkegaard for der at jordes. Det var et høitidelig, gribende Optog. En stor Mængde Mennesker havde forsamlet sig, deels Militaire og deels andre af den simplere Klasse af Byens Indvaanere. Foran $i$ Toget gik 2. Brigades Musikkorps, der spillede en langsom Sørgemarsch igjennem Gaderne, derpaa fulgte et Compagnie af 2den Forstærkningsbataillon, hvorpaa fulgte alle Kisterne. De 2 Capitainer bares af Officerer. En stor Mængde Officerer sluttede Toget.

Efterat Kisterne vare nedsænkede i store lange Grave, og Jordpaakastelsen var skeet, affyredes 3 Geværsalver.

Det var et underligt Syn at see saamange Mennesker staae ved denne Grav, og det maatte være et haardt Menneske, hos hvem ikke en alvorligere Tanke rørte sig; thi vi see jo hver Gang vi følge en falden Kriger hen, at intet, hverken Ungdom eller Sundhed kan beskytte mod Døden, naar den kommer, saa gjælder ingen Persons Anseelse.

Michaeli Kirkegaard gjemmer mange Faldne i denne Krig, baade Danske og Tydske. I 2 lange Grave vedblives der at nedsænkes Kister, den ene ovenpaa den anden, saaledes at man kan see nogle af Kisterne ud mod den aabne Grav.

Efterat Begravelsen var endt, optoges Capitain Kühle og blev ført bort, jeg tænker til hans Hjem. Han var en Søn af den forrige Postmester i Assens og efterlader sig Enke og 2 Børn. 
Frederiksberg, den 17. September 1850.

Inspecteuren over det her ligeoverfor liggende DøvstummeInstitut er igaar arresteret paa Grund af, at han viste sig opsætsig, da der hos ham blev gjort Eftersøgning af skjulte Vaaben $\mathrm{m}$. $\mathrm{m}$.

Tydskerne kan ikke dye sig heri Byen. Man hører mange Historier om dem. Vor Nabokone siger ganske bestemt, at naar vi blive Herrer i Landet, saa vil hun ikke være her et Minut længere, om hun saa skal betle for sit Brød i Tydskland. En anden Pige her i Nærheden siger, at naar hun hører, at den slesvigholsteenske Sag har tabt, saa har hendes Liv Ende, og saadanne Exempler ere her mange af.

Hvor det vil blive noget Mærkeligt, naar engang, som vi haabe, vi blive færdige med denne Krig. Jeg tænker, at en heel Deel vil udvandre for at søge et andet Opholdssted.

I Eckernførde skal Indvaanerne være forvendte for Alvor, derimod gaar det bedre i Husum.

Barakkeleir Nr. 2, den 21. September 1850.

Imorges, efterat Compagniet var afløst og rykket herind, stødte jeg til samme for at være her disse 2 Dage.

$\mathrm{Da}$ jeg kom herud, var det et ganske godt Veir, og den vide Udsigt, som her især er fra dette Sted, glædede mig meget.

De 3 store Barakkeleire, hvor omtrent 3000 Mand ligge, ere opførte her $i$ en lige Linie. Et underligt Syn for hvem, som aldrig har seet det før. Det ligner en lille Bye i Frastand. Denne Plet, hvor jeg befinder mig paa i Aften er og mærkelig derved, at det var her, at Slaget stod den første Paaskedag 1848, da saamange maatte lukke deres Øine.

Man seer her faa Skridt borte en heel Mængde sunkne Grave, der skal være de Faldnes fra hiint Slag.

Forresten er denne Barakkeleir overmaade god, og vi ligge særdeles godt. Alle Ting er iagttagne for at holde Reenlighed og Orden. Foruden en stadig Leirvagt er her desuden Vagt i Compagniegaderne af hver Afdeling, der bivouakerer her. 
Jeg boer tilligemed Vaabenmesteren i Barakken Nr. 19. Her kan jeg sidde i Fred og Roe at skrive. Vi faae om Aftenen leveret et godt Stearinlys, og da her er baade Bord og Bænk, sidder jeg ligesaagodt som i en Stue.

Det er i Aften Regnveir, men Regnen kan ikke trænge ind til os. Vi kan ligge tørt og godt i Halmen og ere derved meget glade.

Frederiksberg, den 26. September 1850.

Idag Morges stillede Compagniet til Appel som sædvanlig og traadte strax af igjen. Siden stillede Underofficerer og Jægere $\mathrm{Kl} .7$ for at modtage nye Klæder, de der trængte til samme.

Atter stillede Compagniet til Appel Kl. 8 og strax, efter at være traadte af nok engang, igjen, uden Bepakning for at modtage nyt Tøi. Dette varede $i$ henimod 3 Timer. Jeg har aldrig travlere end paa saadan en Tid og maae da have Tankerne samlede en Smule for at svare paa mange Spørgsmaal, der gives mig om det og om det.

Det er snurrigt at høre, hvor mange af Folkene have meget at fortælle Capitainen om deres Klæders Tilstand; thi de komme sjældent heldigt derfra, naar de ikke ere paa det Rene.•

Kl. 2 i Eftermiddag stilledes igjen for at sammes Pudsning kunde blive efterseet. Geværerne blev igaar afskudte og skulde nu idag lades igjen.

Det er længe siden, vi egentlig har havt Spectakler ved Compagniet førend nu idag. En Overjæger N... og en Jæger W..... havde ikke været efterrettelige, og Capitainen var meget vred. De bleve haardt tiltalte, især den sidste, for Fronten af Compagniet. - Jeg vilde ikke for meget have taget mod en saadan Lection.

Frederiksberg, den 27. September 1850.

Det lader til, at det bliver til Alvor med det Rygte her er gaaet $i$ disse Dage, at Kongen kommer hertil Slesvig. Han skal være ankommet til Flensborg idag Kl. 11. 
I Flensborg skal der være bygget Æresporte, men det bliver der vist næppe her. Dog har der i Eftermiddag været gjort reent paa Gaden, og Vogne i Hundredviis har holdt paa Gaden og faaet Feieskarnet paalæsset og bortkjørt det.

Imorgen Kl. 10 skal Stillingen besættes ved Dannevirke, til hvilken Tid man venter Kongen.

Tropperne have faaet en Extraportion tilstaaet for imorgen, der allerede er hævet i Aften.

Vi faae hver 16 Lod røget Flæsk og en ${ }^{1 / 2}$ Pægl Brændeviin til en saadan Ration.

Frederiksberg, den 28. September 1850.

Strax efter Appellen idag Morges begyndte der at blive Røre i Anledning af Kongens Ankomst. Tropperne, der cantonnere her i Frederiksberg mødte paa deres Alarmplads enten her i Gaden eller ude ved Busdorf. Jeg lavede mig til at gaae ud til Corpset. Da jeg kom derud, havde samme allerede besat Dannevirke. Jeg fik fat $i$ et Gevær, for at jeg kunde staae med $i$ Geleddet ved Reserven bag Volden og desbedre see.

Det varede længe inden han kom.

Omtrent ved Middagstid kunde vi høre inde fra Byen, at der raabtes Hurra, og alt ordnedes som det skulde være herude.

Hans Majestæt havde der inde i Byen ikke opholdt sig, men red strax ud til Haddeby for at see vores Stilling. 12. Batl. havde der Vagt samt besatte den dobbelte Vold om til vores Corps:

Nede ved Haddeby Noer red han udenfor Volden og kom bag fra samme ind til os.

Endnu har jeg ikke været saa nær ved Kongen. Jeg stod kun et Skridt fra ham. Da han kom til os, spurgte han os, hvordan vi havde det, og til Majoren sagde han: „Tak for Idsted". Majoren udbragte et "Leve Frederik den Syvende“, og der istemtes et trefoldigt Hurra, der gjentoges eftersom Kongen kom til de Afdelinger, der stod i Reserve langs med Volden. 
Paa høire Side af vores Corps stod 5te Liniebataillon, der igjen stødte til 4de Brigades venstre Fløj.

Hvorlangt han red ud, veed jeg ikke, men jeg tænker til Enden af Dannevirke.

Et langt Følge ledsagede Kongen, meest høie Officerer, og der saaes baade russiske og svenske. Prinds Ferdinand var ogsaa med, men da jeg ikke kjendte ham, fik jeg ham ikke rigtig at see.

Veiret var ugunstigt. Det begyndte at regne ved Middagstid og blev stærkere og stærkere, saa vi næsten bleve gjennemvaade, inden vi bleve trukne ind.

Efter at vi vare komne til vores Barakker, gik jeg strax igjen herind til Byen.

Jeg havde seet Kong Frederik den Syvende, og der kom mange Tanker frem hos mig. Om det er nærved en Forandring, som der tales om, i Anledning af Kongens Nærværelse her idag, veed jeg ikke. Gud give at Freden havde været vendt tilbage, og vi endnu under vor gode Konges Septer maatte opleve rolige og stille Dage.

Endnu maae jeg til Slutning tilføie, at Kongen saae bleg ud og er blevet meget corpulent. Han red paa en hvid Hest.

Forpost, Feltvagt paa Ober Selk Mark, Mikkelsdag 1850.

Det blev idag min Tour at komme ud og stødte jeg til Compagniet her imorges Kl. 9. - Det har været en underlig Søndag for mig, men jeg har yæret temmelig godt fornøiet, skjøndt Omstændighederne kun ere maadelige. Vi søge Lye saa godt vi kan i en simpel Hytte for Stormen og Regnen. Et underligt Liv er dette Soldaterliv.

Jeg mindes ikke at have været paa Forpost nogensinde at det har været saa uroligt som idag. - Allerede fra imorges tidlig har man kunnet høre voldsomme Drøn fra høire Fløi udentvivl fra selve Frederiksstadt, der har været lige heftige til over Middag. 
Vi antage, at Fjenden, som nu har prøvet vor venstre Fløi ogsaa vil forsøge, hvad han kan gjøre ved vor høire Fløi. En haardnakket Kamp har der vist været idag, og vi imødesee med spændt Forventning, hvad Udfald den har havt. Vi saae ogsaa, at Fjenden allerede igaar Eftermiddag har forsøgt et Angreb, men bleve slaaet tilbage, og at det Angreb som skete her paa Centrum igaar Eftermiddag ikke har været andet end blot for at hendrage vor Opmærksomhed derpaa for desbedre at kunne opnaae deres Hensigt. - Det samme gjorde de ogsaa idag; thi da Kanonernes Torden henimod Kl. 2 sagtnede ude tilhøire, rykkede han frem mod Krop og mod „det røde Huus“ og Lottorf baade med Infanteri, Cavallerie og Artillerie. Ved Krop og tilhøire for samme kom det til Fægtning strax. Geværilden var temmelig levende og der faldt og enkelte Kanonskud. Nu maatte vi paa Benene alle Mand og der blev strax indtaget Fægtnings-Stilling over hele Centrums Linie. Ordonnantser fløi frem og tilbage. Vi tænkte mon han komme endnu iaften, vi ere færdige, dog da Kampen skjøndt lige vedholdende, kun var ved Krop, bleve Tropperne her trukne ind igjen. Men det varede kun et Øieblik, saa begyndte de ude hiinsides „det røde Huus" og atter vare vi alle i Fægtnings-Stilling. Alle Løbegrave besattes strax bag os og flere Kanonskud hørtes endnu ved Krop. - Alt dette var vist heller ikke andet end for at holde os i Skak. Paa Høiderne bag "det røde Huus" har de vedblevet at fyre enkelte Skud ligetil Aften. Saavidt jeg veed, har vore slet ikke besvaret dem, da de skjøde med Geværer paa 2 a 3000 Alens Afstand. Vore gjorde ved Miner Nar af dem. Ligeledes gjorde de ogsaa igaar, da Tydskerne sendte en 3 tB Kanonkugle imod „det røde Huus“, der ramte det. De toge nemlig Kuglen op i Haanden og viste Fjenden den, idet de svingede med Hatten. De fik nu rigtignok 2 tilsendte derpaa, men de gjorde ikke Commandoet nogen Skade.

Omtrent $\mathrm{Kl} .7$ har vi taget vor egentlige Natstilling, men endnu høres enkelte Skud fra høire Fløi. Stormen er lagt sig, 
og det er blevet godt Veir. Alting er saa tyst og stille. Vi ere belavede paa, at de fjendtlige Commandoer, der have viist sig og endnu staae paa samme Sted forvolde os noget Bryderie inat. Barakkeleiren No. 2, den 30. September 1850.

Idet de sidste Skud langsomt drønende rullede tilhøire tog vi som anført vor Natstilling. Vi fik Forstærkning fra Pikettet mod Ober Selk, sendte mere Mandskab til Lottorf og „det røde Huus" samt besatte alle Barrikaderne og belavede os paa alt mueligt. Sergeant Jerløf, min gode Ven, var kommet ned fra 1ste Compagnie, vi gik lidt frem og tilbage og lægger os i Hytten saadan som den er indtil Kl. 12 da Tannerup ${ }^{4}$ ) kalder ad os, han vilde sove, og jeg skulde tage Vagten lidt i hans Sted. $\mathrm{Kl}$. bliver 2, og vi lægger os igjen. Der falder atter et Kanonskud ved Frederikstad. Vi ligger rolige. Pludselig falder der et Skud i Lottorf. I et Nu var vi alle under Gevær.

„Hr." Øegaard ${ }^{5}$ ) har nemlig staaet og betragtet en Tornebusk og troede tilsidst, at det er Fjendtligt og brænder løs. Dette Skud er nok til at allarmere os Allesammen. Skjoldborg ${ }^{6}$ ) bliver fra "det røde Huus" sendt op og skal see, hvad dette har at betyde. Han kommer dertil, og de troe Alle, at det er Cavallerie, og nu brændes atter løs, Brakker, ${ }^{7}$ ) der har Commandoet i Byen, vil kyse Tydskerne med at raabe, saa det skingrer efter som han commandeerte en heel Batl., skjøndt han kun havde $9 \mathrm{Md}$., da alle de andre vare paa Post. Ved Lieutenant Bagges Feltvagt hører de alt dette og troer der at høre nogen skrige om Hjælp, der kommer Melding ned til os om dette. Gylling ${ }^{6}$ ) er for et Øieblik siden gaaet ud med en Patrouille, og vi troe da, at han er blevet overfaldet. Capitainen giver sig for sin gode Jæger. Atter udsendes Patrouiller for at see efter Patrouillen. Vi vente og vente længe, endelig kommer der Melding, og vi faae den

4) En af kompagniets befalingsmænd.

5) Navnet på posten.

b) Jægere ved kompagniet.

7) Overjæger, blev senere forfremmet til sergent. 
sande Sammenhæng at vide, at hele Allarmen bestod i Angrebet paa Tornebusken.

Skjøndt vi vare allarmerede, og det var lidt ubehageligt, blive vi dog glade, da det ikke var andet, og vi traadte atter af og ventede med Længsel paa Morgenstunden. Den kom, men med Regn.

Det var i Sandhed suurt.

Kl. 7 kom Afløsningen, 1ste Comp. af 3die Batl., og vi marscherte herind til Barakkeleiren under en øsende Regn.

Der var atter Sammenstød i Krop og Kanontorden tilhøire igen. Dog fik vi Lov til at komme i vores Hytte. ived hvilken Glæde kan ingen forestille sig. Der var dem af Compagniet, der siden i Gaar Eftermiddags Kl. 2 havde stadig staaet med deres Tornyster paa, tænk engang i 19 samfulde Timer.

De lagde sig alle $\mathbf{i}$ det glade Haab, at der nu skulde gives Opreisning for den møisommelige Forpost. Men det gaar som Ordsproget siger, man har ikke Ro længer end ens Nabo vil, og vort Naboskab er ikke det behageligste. Vi havde næppe havt en Times Roe, før atter Kanonernes Drøn hørtes ved Krop og ved "det røde Huus".

Strax maatte vi ud og traadte an, flere Kanoner kjørte ud, Geværilden blev mere levende, og vi tænkte: "Mon ikke Tydskerne nu komme her idag, men et Øieblik efter blev det roligt. Fjenden skjød paa saa lang Distance efter vore, at disse ikke værdigede ham et Svar.

Imidlertid gik det som Forpostcommandeuren havde sagt, at naar de Ulderup-Jægere ${ }^{8}$ ) ere paa Forpost, saa komme Tydskere ikke; men derimod naar de blaae Mænd $^{9}$ ) ere der, saa komme de. Disse bleve drevne tilbage fra "det røde Huus", men indtog atter deres Stilling, da det Hele nok kun var som

8) Her hentydes til 3. reservejægerkorps' heldige kamp ved Ullerup i 1849 .

9) Infanterister (i modsætning til jægerne, der var udrustet som let fodfolk). 
de foregaaende Dage, nemlig at forurolige os her, medens de angreb vor høire Fløi.

Vi har bestandig hørt Kanonskud i den Retning og endnu i Aften Kl. 8 har vi hørt et svært Kanonskud.

I Eftermiddag har vor Herre svaret med Torden fra Himlen, og det har regnet meget stærkt. Henimod Aften har her været afskudt Geværer rundtomkring os, og de ved den ene Side have været temmelig uforsigtige. Kuglerne ere gaaede her op over, og i Barakkerne med deres sædvanlige Musik. En gik lige ved min Hytte. Forresten kom dog ingen til Skade.

Det er en suur Aften, regner og blæser.

Jeg takker Gud for min Hytte og min Halm.

(7/10 1850).

$\mathrm{Da}$ Capitainen veed, at jeg gjerne vil see mig om, gav han mig, uden at jeg begjerte det, Tilladelse til idag at gaae til Geltorf og Alte Mühle til de uden for Kjæden detascherede Commandoer.

Geltorf er en temmelig smuk Bye, bygget paa tydsk Maneer.

Glibstrup ${ }^{111}$ ), som havde Vagten, fulgte med mig lidt omkring i Byen, og jeg var inde et Par Steder navnlig hos Skolelæreren.

Jeg saae Stillingen, vi har udenfor Byen, der formedelst det daarlige Terrain er temmelig vanskelig især om Natten.

Hvilke Savn de Beboere, der ere i disse Byer, maa lide, kan man slutte deraf, at de kun har Tilladelse til at bage til visse Tider. Saaledes havde de Lov i alle Byerne, der ligger ved Forposterne til at bage idag fra 10 til 3 .

Jeg saae efter den Grav, som det hed, at Fjenden havde kastet og deri begravet nogle Døde fra en Affaire med 5 Forst. Batl., som jeg har anført for noget siden. Men samme er kun et blot Rygte og ligeledes er der ikke flere blevne saarede af Byens Indvaanere end den ene Mand, der blev streifet i Ansigtet af en Geværkugle.

10) Sergent. 
Paa Tilbageveien fra Geltorf var jeg inde i Alte Mühle, hvor Nielsen ${ }^{11}$ ) staar. Det var en morsom Tour og jeg betragtede ret. de mange forunderlige Indretninger, som Bønderne have her, imod dem i Fyen. Det var konstigt at see, hvorledes de harve deres Korn ned. De have nogle smaae lette Træharver, som en Mand kjører 2 af med een Hest for hver. Den bageste Hest er bundet $\mathrm{i}$ den forreste Harve og skal gaae lige bag efter. Kudsken staaer næsten stille paa Midten af Stykket, og Hestene vedblive at gaae rundt omkring ham. Saaledes saae jeg, der var harvet de fleste Steder.

Barakkeleiren No. 2, den 8. October 1850.

Jeg sad temmelig længe iaftes i min lille Hytte og var rigtig fornøiet over, at jeg sad luunt for Blæsten som tudede udenfor. Endeel af Natten gik godt ved at skrive, og jeg sov ogsaa overmaade godt. Det var en kold Morgen og vi talte om, at det var betydelig koldere end forrige Gang, vi var ude, og herefter bliver det endda værre.

Efter at være afløste af 13. Batls. 1ste Comp marscherte vi tilbage her til Barakkeleiren. Paa Veien talte vi om, at det idag havde været roligt og Tydskerne havde vel andet at tænke paa nu, men næppe vare vi komne ind i Barakkerne, før Kanonskud hørtes ud efter Lottorf og „det røde Huus“, og vi maatte træde an. Der faldt ikke saa faa Skud, men det blev dog ikke til videre. Tydskerne rykkede frem med omtrent et Par Batailloner, og da de saae vore yderste Vedetter, skjøde de strax med Kanoner. Man skulde troe, at det var blot for Lyst, at de saaledes skyde, thi de spilde dog deres Skud aldeles. Ingen af vore bleve enten saarede eller dræbte.

Efter at have holdt os parate $\mathrm{i}$ en Timestid, fik vi Roe og har været glade ved Barakkerne. Det har været koldt og stormfuldt hele Dagen, og iaften er det stærk Regn. Det regner ned paa Bordet og overalt i alle Barakker, da Regnen er meget voldsom, men her er dygtig Halm, saa vi kan nok putte os ned.

it) Overjæger. 
Det er sandelig et underligt Liv.

Idag bliver gjort en Begyndelse med Udlevering af Riis, som vi skal have i stedet for $\mathbb{E r t e r}$, dog kun hveranden Gang. Portionen pr. Mand er $1 / 2 \mathrm{Pd}$.

Frederiksberg, den 9. October 1850.

Efter Tour skiftede 2. og 5. Brigade idag igjen, 10de Bataillon kom ind med fuld Musik. Det er en rask Bataillon, og dens Commandeur Oberstlieutnant v. Ræder skal nok rappe den op. Det er en rask Mand, der altid er i Bevægelse. Jeg mødte ham idag paa Dæmningen, og da jeg hilste, sagde han: „Goddag min Ven“. Naar han er i den Lune, er han god, men paa den anden Side er han streng."

Den 10/10 ledsagede Morten Nielsen sin kaptajn på en tur til Frederiksstad.

Som vi alle ved, var fjendens storm på denne by afslået den 4 . i samme måned. Det sejge og udholdende forsvar, som besætningen i Frederiksstad gennemførte med så heldigt et resultat, har med rette gjort denne dag til en af hærens mindedage. Men i vurderingen af kampen må det ikke glemmes, at det resultat, vi nåede, i en ganske særlig grad skyldtes de personlige karakteregenskaber hos kommandanten, obert Helgesen, hvis uforfærdede mod og sejge udholdenhed indgød alle hans undergivne tillid og kampvilje under de vanskeligste forhold, og han bærer derfor en stor del af æren for, at denne sidste store kamp under treårskrigen fik det for os så gunstige udfald.

Der synes ikke at være tvivl om, at den rejse, kaptajn v. Bruns og hans fourer, foretog, var en ren udflugt, og det blev også taget som en sjælden oplevelse af Morten Nielsen.

Rejsen foregik med vogn over St. Danevirke-HollingstedOstenfeld og Husum. I Ostenfeld skiftedes heste, og de to „turister" bemærkede i denne by med undren de egenartede folkedragter, hvorom Morten Nielsen fortæller:

„I denne Bye saae vi endnu nogle Fruentimmere, som havde 
deres gamle Nationaldragt. I Førstningen troede vi, at det var en Narredragt eller saadant Noget. De havde en rød Trøie paa af Skind med store Opslag og gule Snore baade for og bag og et sort Stykke som en Rabat ned ad Brystet. Det var den konstigste Dragt, jeg har seet i mine Dage.“

En mand med et så opladt sind som Morten Nielsen måtte naturligvis blive stærkt betaget ved synet af marsken, som han indgående beskriver. Her vil det dog føre for vidt at gengive dette, derimod er der mere anledning til at høre hans skildring af Frederiksstad, der efter det voldsomme bombardement havde lidt en del.

„Endelig naaede vi Frederiksstad. Maalet for Reisen. Hidtil havde alt, hvad jeg havde seet fordetmeste været glædeligt, men med Et frembed sig noget andet for mit Øie. Allerede ved Indkørselen til Byen kunde vi see, hvorledes enkelte Huuse vare gjennemborede af Kugler, ja aldeles som Pjalter og Stumper. Dog det var intet mod det, som var inde $\mathbf{i}$ Byen.

Vi kom ind ad den sydlige Port over en Kanal.

Hvilket Syn, en stor Steenhob. Hvor det saae rædsomt ud. En Ødelæggelse som denne har jeg aldrig før seet. Jeg antager, at omtrent de trefemtedele af Byen er aldeles ødelagt, og ingen skal her kunne see, hvor skjøn Staden har været. Det gjorde et haardt Indtryk, og sandelig - det maae røre En at see saadant et Syn. Saalænge jeg lever vil disse Ruiner staae mig i Minde.

Der blev nu fraspændt, og vi gik da ud for at see Forsvarsværkerne.

Paa den nordøstlige Side af Byen laae en Skandse, Treneskandsen kaldet, lige med Chausseen efter Rendsborg laae Centralskandsen, som vi først var ved, og uden for samme laae et stort Blockhuus, hvilket ved Stormen var i Tydskernes Magt, hvorimod Skandsen ikke var stormet. Derfra kom vi til Mølleskandsen sydvest for Byen paa et Dige, der er opført langs Dideren. Her var det især, Fjenden havde forsøgt Storm. Hele Da- 
gen den 4. havde han uafladeligt beskudt dette Værk fra et Batterie med 12 Kanoner ovre paa den modsatte Eiderbred, kun 600 Alen borte, og fra Kanonbaade i Eideren. Værket havde lidt betydeligt, og han troede nu, at det mod Aften var den rette Tid at gaae løs.

Jeg hørte en Lieutenant af 1 . Res. Batl., som havde været med den Aften, fortælle, at det var noget af det Rædsomste, som kunde tænkes, da Stormen begyndte. Alting var oplyst af den brændende Bye bagved, og foran sprudede Død og Ødelæggelse. Fjenden var flere Gange nede i Skandsen, men den lille Besætning drev ham hver Gang tilbage. Besætningen var af 7. Batl., ialt 7 Underofficerer og $70 \mathrm{md}$, og af disse kom kun 2 Underofficerer og $22 \mathrm{md}$. usaarede derfra. Udenfor laae endnu Blod, som flød den Aften, og en Mængde Kugler af alle Sorter.

Skandsen var atter istandsat, og i Gravene paa Diget, hvor Vandet ei kunde komme, laae en Masse Harver med Tænderne iveiret, og alt var belavet paa, om et nyt Angreb skulde skee.

Vi vilde have været ned fra denne Skandse for at see Eideren, men der blev os sagt, at det var ikke værdt, da vi risikerede at faae en Spidskugle fra det ligeoverfor liggende Batterie, hvor en lille Vagt stod, der hver Dag skjød paa vore Arbejdscommandoer. Vi kunde see dem derovre, og vi betænkte os og gik tilbage.

Vi kom nu til Kalkværksskandsen og siden til 2 Kanoner, der saaledes var placerede, at de kunde bestryge Diget langs Eideren. Disse 2 Kanoner og deres Besætning vare næsten begravne hele Dagen, og de kunde ikke bruges før om Aftenen, da Stormkolonnerne kom, men da skal de og have anrettet en frygtelig Ødelæggelse. De havde i Mørket, som var udad, ikke andet at rette efter end Geværernes Ild, og de skal have truffet godt alligevel.

Dagen før vi var der, blev paa Mølleskandsen udgravet en af de fjendtlige Soldater, af hvis Papirer der saaes, at han ganske nylig havde tilgaaet Armeen som frivillig. Det var en Ber- 
liner Skræddersvend, som mulig havde troet at hente Laurbær. Her laae han og alle hans Planer med ham. - Endnu maae jeg tilføie, at der ud ad Marsken efter Bomhuset laae mange Creature, der vare skudte.

Den reformeerte Kirke var brændt. Den catholske stod endnu, men alt det indvendige var brændt og laae paa Gulvet. Jødesynagogen stod ogsaa, kun 3 Kugler vare gaaede igjennem dens Mure. Den var opfyldt af Soldater, der havde deres Tøi hængende paa Væggen ved Siden af de hebraiske Tavler. Paa Alteret laae hebraiske Skrifter, der kun af Soldaterne bleve betragtede som andre ligegyldige Ting. Den sidste Kirke, jeg var i, var den lutherske, her laae 3. og 4. Comp. af 5. Bataillon. Hele Kirken var fuld. Nogle spiste og drak, nogle skrev, andre sov, nogle spillede paa Orgel. En stod paa Prædikestolen og havde sit Tornyster lagt, hvor Præsten lægger sin Evangeliebog. Det var et underligt Syn at see en Kirke som Kaserne.

(11/10 1850).

Der var iaften lidt Uorden i Cantonnementet, og jeg maatte ud at holde Styr. No. $76 \varnothing \ldots$... var blevet reent balstyrig og vilde endog prygle en Overjæger. Jeg blev sat i den Nødvendighed at bruge haardere Midler mod denne Fyr. Vi havde besluttet, Overjægeren og jeg, at melde ham imorgen, hvis ikke han vil falde tilføie, og hans Straf vil blive haard for Alvor."

I oktober kom en række tildelinger af dekorationer. Ved 4. kompagni blev således 3 dannebrogsmænd. Kaptajnen havde selv udpeget to, den tredie var indstillet efter afholdt valg.

Det kan måske være af interesse at nævne, at da valg afholdtes for at bestemme, hvem der skulle indstilles, var der først 5 forslag ved kompagniet (og alle blandt de sårede). Ved et omvalg (de to kandidater i sidste omgang havde hver mistet den ene arm) sejrede en bondekarl, underjæger Refning, med mere end dobbelt så mange stemmer som den ligeledes fraværende modkandidat, der var københavner. Men hovedparten af 
kompagniets mandskab var også bønder. Den dekorerede underjæger døde imidlertid et par dage efter.

Om ordenstildelingerne skrev Morten (den 16.j10. 1850):

„Saameget derom. Skjøndt det iaar er meget respectable Karle næsten allesammen, der ere værdige til at hædres, er jeg dog overbeviist om, at mange vil see skjævt til dem. Det er ikke anderledes og bliver heller aldrig anderledes. Hvad dem ved vores Compagnie angaaer, da har ingen mindste Grund til at være fortrydelige. De have alle været særdeles raske i Slaget ved Isted og kjæmpede med Mod og Tapperhed, ligesom og deres Forhold til andre Tider har været overmaade godt. Kun undrer det mig meget, at vor Vaabenmester ikke er blevet Dannebrogsmand. Han har i 2 paa 3die Aar været frivillig. Ifjor var han indstillet, og saavidt jeg veed har han ogsaa været det iaar. Han har ingenlunde været heldig.

I disse Dage er der udgaaet et Opraab til hele Armeen om at bidrage lidt til de ulykkelige Frederiksstædtere og navnlig give hver en Dags Lonning eller Gage, men det lader ikke tii at blive til Noget. Den Menige seer skjævt dertil og vil ikke, som han siger, give noget til det tydske Pak, og jeg forundrer mig ikke derover; thi de Fleste kunne jo ikke see andet end at alle Beboerne her staae imod dem. Dog det var jo en Christens Pligt at hjælpe, og dersom derved nogle af de Forvildede kunne vindes, var det $i$ Sandhed godt.

$(17 / 10$ 1850).

Compagniet stillede til Appel i Eftermiddag Kl. 41/2. Det igaar omtalte Opraab blev oplæst, men som sagt det fik intet Gehør.

Frederiksberg, den 18. October 1850.

Compagniet stillede til Lonningsparade $\mathrm{Kl}$. 41/2 Efterm.

Vi havde idag en nye Jæger ${ }^{12}$ ) nemlig den forrige Hornblæser Larsen.

12) Her er tale om en forfremmelse. 
Ved Paraden blev Overjæger Brakker fremkaldt og gjort bekjendt med, at han idag er for sit gode Forholds Skyld, navnlig for sin Condouite forleden i Lottorf, tildeelt Sergeants Characteer.

Endelig blev No. 162 Hansen fremkaldt. Han blev rød i Ansigtet og troede maaskee, at der havde været noget iveien, han tænkte mindst paa det, han skulde. I den afdøde Underjæger Refnings Sted er han ogsaa under 6te ds. benaadet med Dannebrogsmændenes Hæderstegn. Han havde ikke i mindste Maade anet det og blev derfor saa aldeles overrasket, at jeg synes ei før at have seet et saadan Tilfælde. - Nu tæller Compagniet 6 Dannebrogsmænd.

Compagniet skulle idag afgive Betænkning, om de vilde give lidt til de betrængte Frederikstædtere, men da de skulde træde frem, kom ikke een eneste af de Menige. Vi vare syv Underofficerer, der deels vilde give hver en Dags Lønning, deels 1 sk. pr. Md. Capitainen gav sit Bifald tilkjende derved, at han vilde lægge Pengene ud og betale for os, siden skulde han nok huske det.

Frederiksberg, den 19de October 1850.

De 2 foregaaende Dage vare paa en Maade glædelige Dage, da nemlig alle de Forfremmelser og Udnævnelser skete ved Compagniet.

Idag blev det noget ganske andet.

Kjøge ${ }^{13}$ ), som vi alle kjende godt fra Historien med Pengene i Miang i Vinter, har atter gjort Knuder.

Han stjal i Morges omtrent 6 Pd. Kjød fra en Slagter ved Siden af dette Quarteer. Mistanken faldt strax paa ham, da Kjødet savnedes, og da vi tillige hørte, at han $i$ den tidlige Morgenstund havde stegt Beuf, hvilket var paa en Tid, da vi vidste, at han ikke kunde have noget af $\sin$ Naturalforpleining, faldt det Capitainen ind, at det ingen anden kunde være end ham.

13) En af kompagniets menige. 
Capitainen, som i de foregaaende Dage havde været glad og fornøiet, var idag meget vred. Vi fik en heel Deel Renderier, som altid vanker ved saadanne Leiligheder, da her atter vare flere med i hans Selskab uden dog egentlig at være Medvidere i Tyveriet. Da disse alle havde været hos Capitainen, kom Kjøge ind.

Jeg kom ind i Capitainens Sovekammer og hørte der, hvorledes Capitainen tiltalte ham. Først tog han det med det gode og forelagde ham, hvormeget det laae ham paa at kunne have hjulpet ham. I Foraaret, da det var galt, bad han for ham, og hans Straf blev formildet, hvorimod han lovede ham igjen aldrig at komme saadan afsted. „Jeg har foreholdt dig som en Fader sine Børn; men du har ikke lydet mig. Du er atter fældet."

Capitainen fik ham blødgjort og omsider, skjønt flere Gange at have nægtet det, bekjendte han under en Strøm af Taarer, hvis lige jeg ei før har seet.

Det var ogsaa mærkeligt, at han nu efter et halvt Aar at have været i de Meniges 2den Klasse, skulde atter have erholdt Kocarden. Idag skulde det netop have været indstillet til Corpset og imorgen havde han igjen været en ærlig Karl. Saa stjæler han netop idag Morgen og er nu nærmere ved at komme i Forbedringshuset end faae sin Kocarde. Dette foreholdt Capitainen ham alvorligt bagefter og foreholdt ham vor Herres forunderlige Styrelse, at han ikke skulde komme vel fra sin Gjerning. Og sandelig det var ogsaa mærkeligt. Jeg synes næsten ikke at have hørt noget lignende. Det Øieblik, da han stod for Capitainen, glemmer jeg aldrig. Jeg blev tilsidst rørt og kunde næsten ikke holde mine Taarer tilbage - deels ved at høre paa Capitainens sunde og alvorlige Tale og [dels ved at] tænke paa den Stilling, hvori Kjøge stod.

Forbryderen er i Eftermiddag afgivet til Pladscommandantskabet her i Byen, og Forhør og Krigsret vil blive afholdt over ham.

En haard Straf venter ham. 
$(27 / 1050)$.

Vores Adjudant Prmlt. v. Thorstensen og Lieut. v. Schmergel ere udnævnte til Capitainer eller rettere tillagte Capitains Characteer. Det kan ikke nægtes, at vi vil komme til at savne disse to Officerer ved Corpset, thi vi antage jo, at de snart forlade os for at ansættes som Compagniecommandeurer ved en eller anden Bataillon.

Frederiksberg, den 29de Octobr. 1850.

$\mathrm{Da}$ vores Brigade imorges rykkede ud for at afløse 5te i Forposttjenesten, var her i Frederiksberg et af de smukkeste Syn, jeg har seet her endnu, idet 13. Bataillon stod opstillet paa begge Sider af Gaden og 12 te kom med fuld Musik marscherende igjennem den. Strax derpaa fulgte 13. Batl. efter og idet samme 10de om ad Gaden ad Dannevirke til, alle med Musik. Det var smukt at see alle disse Troppers tactmæssige Bevægelse.

Jeg er, som jeg pleier van, fløttet ned til Collstrop ${ }^{14}$ ), hvor jeg har det overmaade godt.

Baptisten Clausen, som her boer, der ved vores Ankomst den 25 de Juli flygtede med Tydskerne, er endnu ikke kommet tilbage. Hans Svoger Teglbrænder Jürgensen, som jeg iforgaars besøgte, fortalte, at han havde skrevet efter ham. Jürgensen sagde, at han var flygtet, fordi han troede, at han havde blevet taget som dansk Soldat.

(30/10 50).

Af Dagsbefalingen seer jeg, at de, som herefter findes sovende paa deres Post, skal stilles for en Standret istedet for som hidtil for en Krigsret.

Efter at have faaet min tilbørlige Morgensøvn gik jeg fra Frederiksberg for idag og imorgen at være med Compagniet. Samme er idag længst ude, og jeg havde et godt Stykke Vei at marschere. Det regnede stærkt, og jeg var næsten gjennemblødt, før jeg naaede hertil, og Hytten var mig derfor ret vel-

14) Skriver ved korpset. 
kommen, skjøndt den ikke rigtig kunde holde tæt. Henimod. Middag blev det Tørreveir, og Eftermiddagen har været ret behagelig.

Ved Middagstide gik Sergeant Glibstrup og jeg til Lottorf deels for at see denne Bye og deels see Sergeant Brakkers Stilling.

Lottorf er en middelmaadig stor Bye. (Der er ikke en eneste Skorsten i hele Byen). I en Gaard, hvor vi var inde, morede vi os over at see 3 af Mandens Døttre og 1 Karl tærske sammen. Det saae konstig ud. Langs med begge Sider, hvor de tarsk, stod Køerne med Hovederne ud i Loen og kunde næsten naae at æde af Vængen. For Enden af Loen var Stuerne, hvor vi og vare inde. Folkene vare flinke, og vi fik Mælk og Mjød at drikke, saa vi vare ret fornøiede over vores Tour.

Det bemærkes, at Kjæden staaer midt imellem Feltvagten og Lottorf, og det Commando, som er i denne Bye, er altsaa udenfor. Sergeant Brakker staaer i den sydlige Udkant af Byen og besætter nogle Høider tæt syd for samme. Herfra er en overordentlig Udsigt over den i Syd og Vest beliggende milelange flade Strækning af Mose og Lyng, der er den største i sit Slags, jeg nogensinde har seet. Ligefor os i Syd laae Rendsborg, og vi kunde see 2 Kirkespire derinde. Ved Brekkendorf og syd for Krop kunde vi see enkelte Tydskere. Ligefor synes næsten ikke at være fremkommeligt, da Vandet staaer temmelig høit flere Steder ud af Mosen.

Det er ellers en stor Skade, som disse Bønder heromkring have lidt iaar, idet de ikke har faaet deres Tørv, der staaer ude i Mosen. Saalangt Øiet kan naae, staae Tørvestabler, og det er ikke mueligt at faae mere for iaar, om og der havde været Fred.

Disse Beboere, som ere i Byerne, hvor Forposterne staae, faae rigtignok at vide, hvad Krigen giver. De gode Fyenboer vilde ordentlig krympe sig ved, dersom de, som jeg saae idag, at Mændene i Lottorf, den ene efter den anden, var hos Vagtcommandeuren for at erholde Tilladelse til at pløie osv. De maae 
ikke engang kjøre til nærmeste Nabobye. En Soldat faaer Heste og Vogn, og saa kjører han. Da jeg gik fra Lottorf, saae jeg netop En af vores Compagnie komme kjørende med noget $\mathrm{Kj}$ ød, som skulde over til Jagel. Han sad paa Vognen med Pidsk og Tømme i Hænderne, Geværet imellem Benene og Tornystret paa Ryggen, der forresten saae ret comisk ud.

$(8 / 1150)$.

Jeg blev vækket imorges Kl. 51/2. Det regnede og stormede forskrækkeligt udenfor. Jeg tænkte, matte Du dog bare have blevet, men det hjalp ikke, hvad jeg tænkte og ikke tænkte. Jeg kom op og fik kaldt ad Tinna ${ }^{15}$ ), og hun kogte mig et Kop Caffe, og da jeg havde drukket det, spankede jeg af.

Gaden var i eet Søle og regne gjorde det. En lidet behagelig Tour saa tidlig om Morgenen. Dog maae jeg sige, at naar man veed, at det skal være, gaaer det bedre. Jeg fandt mig ret godt deri. Da jeg kom til Compagniet i Barakkeleiren, var Corpset ved at træde an til Afmarsch for at afløse Forposterne, og jeg kom strax paa Marschen igjen. Vores Compagnie skulde idag til Selck Mühle. Vi afløste 13. Bataillons 4de Compagnie, der saa igjen skulde afløse os i Barakkerne. Her er igrunden ingen Forandring skeet siden jeg var her sidst. Compagniet, der idag var $187 \mathrm{Md}$. stærk, er saaledes fordeelt:

Pikettet 76 Md., Vagten ved Møllen 79, Vagten ved det hvide Huus 12, Vagten ved Broen 6, Commandoet paa Korsveien ved Essperehm 14.

Vagten ved Møllen har udsendt Commandoer til Geltorf og Alte Mühle, hvis Størrelse dog ei er mig rigtig bekjendt. Pikettet har om Dagen 3 enkelte og 3 dobbelte Poster at udsætte, hvormange Poster de andre har om Dagen, veed jeg ikke, ligesom Natstillingen er mig og ubekjendt.

Vi har faaet $60 \mathrm{Md}$. til Forstærkning fra Pikettet ved Vedelspang, som skal til Patrouiller og til at forstærke de enkelte Vagter, især de forreste Commandoer.

15) Eller Tine, en af pigerne i Mortens kvarter i Slesvig. 
Idag har det dog været temmelig oventørt, men Føret er forskrækkeligt. Møllen ligger lavt, og dem, som ere heromkring gaae i Pludder til midt op paa Benene, naar de skal paa Post.

Jæger Bjelke ${ }^{16}$ ) kommer i dette Øieblik ind og har ført Afløsningen op og er frygteligt tilsmurt om Benene. Imidlertid gaaer det dog ret godt. Soldaten har et frit Mod; vel onske v1 alle, at det var tilende, men jeg kan dog sige med Sandhed, at vi langtfra ere forsagte.

Da jeg havde været her i et Par Timer, gik jeg ud til Geltorf, meest for at kjøbe nogle Gjæs, som flere havde bedt mig om (vel at mærke, det er snart Mortensaften).

Jeg blev i Geltorf og besøgte flere af Bønderne tillige med Sergeant Glibstrup til Klokken henimod 3, og det var een af de morsomste Toure, jeg har havt endnu. Først besøgte vi en Mand, som hed Claus From og spiste der Grød og Pandekage til Middag. Manden stod i sit Huses Dør (nemlig den, hvor Røgen gaaer ud af) og tog imod os og var nok saa flink. Siden besøgte vi Skolelæreren og drak der Caffe nok saa fint. Jeg saae hans Bibliothek og fik fat i nogle Bøger, og vi læste begge, den ene for at lære dansk, den anden for at lære tydsk. Han sagde, jeg godt kunde læse tydsk, og jeg læste fort og var stor paa det. Her maae jeg ellers bemærke, at man i hvert et Huus, man kommer ind $i$, seer en Bibel eller nye Testamente eller anden gudelig Bog. Hos Skolelæreren saae jeg nogle af Gjendøbernes Tractater, dog troer jeg ikke, han er Baptist. Tilsidst besøgte vi „der Bauervogt" eller Sognefogden og maatte der atter have Caffe. Al denne Beværtning kostede os ikke noget. Det sidste Sted iik vi endda nogle $\mathbb{E}$ bler til.

Det var en ret fornøjelig Tour, men for Glibstrup er det i een Henseende mindre behageligt. Han har sine Instruxer at rette sig efter, og ingen maae hverken bage eller pløie uden Forlov. I den Tid, jeg var der, troer jeg over 10 var hos ham for at bede om Et eller andet, og han vilde jo gjerne hjælpe dem, da

16) En af kompagniets jægere. 
Enhver kan nok vide, hvor nødvendige saadanne Ting ere som pløje og bage.

Vi fik da og nogle Gjæs, ikke mindre end 5, og jeg fik dem læssede paa den ene Ambulancesoldat, og saa gik jeg tilbage til Vagten.

Efter at jeg havde været ved Pikettet ved Vedelspang for at afskrive Ordren, fik jeg Lov at gaae herned i Møllen og blive her i Nat, som jo er noget bedre end at ligge i Hytten. Her sidder jeg i en god Stue, har faaet mit Thee og Smørrebrød, og jeg giver dem Ret, som siger, at jeg kan sagtens; thi jeg har det $i$ Virkeligheden langt bedre end de allerfleste i Compagniet.

Fredriksberg, den 11. Novbr. 1850. Mortensdag.

Vi spiste saa vores Mortensgaas iaftes, Kløvborg, Rantzau, Wiegand, Collstrop ${ }^{17}$ ) og jeg, og det saa godt som vi kunde efter Omstændighederne. Ovenpaa drak vi et Glas Punsch og vare ret godt fornøiede, at vi kunde sidde i Fred og Roe.

Jeg var glad, at det var ikke saadan en Mortensaften, som den vi holdt ifjor i Sarup. Dog tror jeg, at her i Nabolaget har været holdt en lignende omtrent af de fleste, som deeltog i den ifjor. Jeg saae Selskabet et Øjeblik, men de vare slemme skjæve de fleste af dem, om det saa var nogle Piger, som vare med. De bleve tilsidst heelt dansksindede og sang den tapre Landsoldat, som Selskabet jo var nok saa fornøiet ved.

Dog det kan være nok om dette.

(15/11 50).

Da jeg i Eftermiddag var ude i Byen, kom en stor Mængde Vogne fra Husum Veien, som havde været paa Arbeide der ud ad Hollingstedt til. Ogsaa disse civile Kudske føle lidt af Krigens Tryk. De ligger i Barakker nord for Gottorp Slot ligesom vi andre Soldater, og de maae endda ligge der bestandig.

Dersom Slesvig var saa jammerligt et Land, som man skulde troe af de Heste, Vogne og selve Kudskene, som ere i Æggt, saa

17) En række af korpsets underofficerer. 
var det kun simpelt. Man seer næsten ikke eet eneste Par gode Heste eller en ordentlig Vogn. Kudskene ligne alle nogle Stympere, og det Hele danner en stærk Modsætning til det, vi før har hørt om Slesvig.

(17/11 50).

Her forestaar nu en lang Nat, men jeg er glad ved, at jeg er fri for at staae paa Forpost. Jeg har intet andet end at passe mig selv. Capitainen byder mig hver Aften, vi er her, ind til sig for at faae et Kop Thee, og jeg har ogsaa været inde hos ham i Aften og synes, jeg er godt skikket til at tage mod Natten.

$(20 / 1150)$

Idag er udleveret 1 Koge- og Varmeovn til hver Barakkeleir, men hvorledes disse skal benyttes er mig ikke bekjendt.“

Den 24. november drev et fjendtligt rekognosceringskommando en lille postering (af korpsets 1. kompagni) ud af Lottorf. Der kom imidlertid omgående stette bagfra, og fjenden blev hurtigt kastet ud af byen, hvor en gård og to huse var stukket $i$ brand.

„Hvem der skjød Ild paa Byen veed Ingen, men Tydskerne faaer Skylden, og Beboerne nære den største Foragt for dem og kalde dem Røvere og Mordbrændere.

Fjenden var som rasende, da han kom ind i Byen og undersøgte hver en Gaard og Huus paa det nøieste. I en Gaard skammede han sig ikke ved at stikke med sin Bajonet $i$ en Seng, hvor Konen laae, og i en Vugge, hvori laaet et lille Barn. Manden traadte til og sagde, om de vilde slaae nogle ihjel, kunde de slaae ham ihjel, men de andre skulde de lade ligge, hvorpaa han blev banket dygtigt af.

Den hele Affaire har været hæderlig for os, og Skjerning (en Underofficer af 1. kompagni) er kommet godt derfra. E'en Mand af 1ste Compagnie, en Cujon; løb derfra, ned til Vagten til Capitain du Plat og meldte, at de alle vare tagne. Han har i Dag til 
Straf gaaet med en Kost frem og tilbage ved Compagniets Barakker. Godt nok til ham.

Frederiksberg, den 6. December 1850.

Den Armaturcommission, som vi nu i flere Dage har pudset og ordnet alting til, foretog endelig idag Eftersyn her ved Compagniet. Kl. $11^{1 / 2}$ stillede Compagniet i Skandsen denne Side Busdorfer Teich. Næstcommanderende [ved korpset] foretog Eftersynet. Det gik overmaade godt, kun nogle Enkelte havde ikke pudset godt, hvilke bagefter bleve raabte frem, og disse fik saamænd en drøi Lection. Især fik Corporalskabsforstanderne, hvad der stod paa Sedlerne. Næstcommanderende var da gaaet. Jeg vilde ikke for alt have været i Overjæger Nielsens Sted. Han er slem kommet i Capitainens Kløer. Flere Gange har det været galt, men i Aften blev det endinu det værste. Han maatte fratræde sit Corporalskab til en anden Jæger og blev ansat ved Glibstrups Corporalskab som Medhjælper.

Det maa være drøit for en ærekær Soldat.

$(7 / 1250)$

Af Befalingen idag sees, at der istedetfor røget og saltet Flæsk vil indtil videre blive uddelt Klipfisk, Risengryn og Smør. Hver Mand er tilstaaet 1/2 Pd. Klipfisk og 2 Lod Smør.

Frederiksberg den 21. December 1850.

Atter idag kom Pengebreve, ikke mindre end 77 til Corpset, hvoraf 20 til Compagniet. Vi beundre rigtignok den store Gavmildhed, hvormed Nationen kommer sine Sønner ihu. Jeg troer ikke, der er mange Sogne i Fyen,undtagen de nu have givet Penge til Soldaterne. Det glædede mig iaften at see Pastor Maus' Haandskrift paa et af disse "Sognebreve“, der var til en Karl fra hans Menighed.

$(22 / 1250)$

Indvaanerne her i Byen, der efter de danske Soldaters 5 Maaneders Ophold her ere endnu lige tydsksindede, vente ogsaa, at nu skal det snart blive godt. 
Det skjærer i mig at tænke paa, at de arme Mennesker ere saa hildede, at de ikke kan dye dem. Man tænke sig engang Tinne her, kun 17 Aar gammel, saasnart som vi sidder og taler om, at Insurgenterne skal have Bank, som hun nok kan forstaae, saa triller den ene Taare efter den anden ned af hendes Kinder. Jeg har iaften seet hende i Løndom græde, og dog vilde hun søge at dæmpe sig, for at vi skulde ikke see hende. Hun gik tidlig iseng og kom ind i min Stue for at hilse af med mig, da hun nu ikke kunde være ved de andre mere for deres Pral. Ja jeg maa tilstaae, at hun har tidt givet mig nok at tænke paa. Det er en hjertensgod Pige, og jeg skal aldrig glemme hende for hendes Godheds Skyld; men jeg kan heller ikke glemme, at hun kan være saa forsikkret,om Oprørernes Sag er rigtig, at saadan og saadan er det. Hun har flere Gange sagt til mig, at til Juul kom "vores Tropper" „unsere Leute“, saa er hun glad.

Er det dog ikke forskrækkeligt. Hvad skal vi dog sige, naar det kan blive saa indgroet $i$ et Pigebarn paa 17 Aar.

\section{$(24 / 1250)$}

Soldaterne ere fra Leirene og Byerne heromkring inde i Byen i Eftermiddag for hver at kjøbe sig en lille Smule, hvormed de vil gjøre sig Juleaften saa behagelig som muligt, og det kan nok være, at de Handlende kan mærke, at her ligger en Armee 1 og om Slesvig.

Saa er det igjen Juleaften.

Der er ikke mange Familier trindtomkring i Landet, naar de iaften sætter sig tilbords for at spise Nadvere, uden de ihukomme en Fader, Broder, Søn, Beslægtet eller Ven, som de savne, der enten er død eller ligger her i Slesvig. Mangen Gang vil der blive sagt: „Hvordan mon han har det iaften“.

Ogsaa i mit Hjem vil dette blive sagt, ja jeg veed det godt, at de ihukomme mig, og jeg ihukommer ogsaa dem. Denne er den anden Juleaften, som jeg ei har tilbragt i deres Kreds. Gud maae vide, om jeg næste Juleaften, - hvis vi leve saalænge, - 
maae være hjemme. Det veed ingen uden Han alene, som raader for vor Skjæbne, og til Ham vil vi overlade det.

Kløvborg, Collstrop, Rantzau, Wiedgand, Holm og jeg have spist Julenadvere i Samling. Vi havde kjøbt os nogle Brasen og har faaet os saa god en Nadvere, som vi kan ønske.

Dog fattes der noget, og det er Hjemmet. Jeg kan ogsaa mærke paa Pigerne, at de fattes noget; thi de ere saa tavse. De vil ligesaa længe som vi mindes denne Juleaften.

Barakkelejr No. 2 den 26. December 1850. Anden Juledag.

Jeg gik Kl. 8 imorges herud for at tilbringe Julefestens 2den Høitidsdag i Barakkerne. Det har været et godt Veir, og det er ret taaleligt at være her endda.

3die og 4de Compagnies Brandstue er nu saa nær færdig, at vi næste Gang, vi kommer her, kan være der Allesammen. De Meniges Stue har været afbenyttet, alligevel den ikke var færdig. Det er en ordentlig Stue. 4 Kakkelovne staae midt paa Gulvet, der skal opvarme den. Omkring ved Væggene og midt paa Gulvet staae Borde og Bænke. Det var overmaade varmt, da jeg var derovre og var meget bedre at sidde der end her i No. 19, men der er en frygtelig Mudder, og jeg vil desaarsag hellere være her.

De nye Koge-Indretninger ere ogsaa færdige fra imorgen af og kan afbenyttes, saa Mandskabet nu kan koge i Huuslye og spise i Brandstuen. Hvergang vi komme herud, bliver her mere at tage Vare paa, men nu er det og snart godt, og vi ere ingenlunde kjede $i$ at være her.

Iaften fryser det igjen og sèr ud til, at vi maaskee kan faae lidt Vinter. Vi bemærke det Alle, naar det saaledes begynder at fryse; thi vi veed vor Fjendes Mening, men der er ikke en Soldat, uden han siger: „Lad ham kun komme. Alting er beredt til at tage imod ham med."

Jeg var i Eftermiddag oppe i Valdemarskandsen og saae der et nyt Telt til at forbinde Saarede $i$, som er opført $i$ de sidste Dage. 
Frederiksberg, den 27. Decbr. 1850.

Det bliver snart kjedelig at skrive i min Dagbog; thi det er lige Et og det samme altid. Vi veed iforveien, hvor vi skal hen, og der er ikke en Karl i Compagniet, uden at han kjender det.

Idag her i Frederiksberg, imorgen i Barakkerne, næste Dag ved Hovedpikettet, Møllen, Geltorf, Lottorf, "det røde Huus“ osv.

Idag har Compagniet været paa Forpost ved Selk Mølle. Jeg forblev i Leiren efter at Compagniet var afmarscheret for at aflevere Inventariet, hvorefter jeg marscherte til Selk og har været der hele Dagen.

Efter at jeg havde skrevet Befalingen af, gik jeg med Collstrop tilbage her til Byen for at blive her inat.

Intet Nyt er forefaldet ved Forposterne idag. Vi har paa Grund af stærk Taage havt Natstillingen ${ }^{18}$ ) ude hele Dagen.

$(28 / 1250)$

Det bliver snart saa travlt for mig, som om vi kunde ligge $\dot{\bar{i}}$ Garnison i Hovedstaden. Det stiger daglig.

Idag har jeg havt mit Spil igjen med Quartererne, med deres Aflevering, med Tæpper, Leirsække og øvrige Inventarium. Alt skal gaae saa regelmæssigt tilværks som sagt, som om det var et reent Garnisonsliv, vi førte.

Munderingsrapporten med flere Ting har ogsaa beskjæftiget mig idag.

Jeg afskrev iaften Parolen. Ved samme udgaves til respective Compagnier 126 Pengebreve, hvilket er det største Antal, der endnu er kommet paa eengang. Jeg modtog ogsaa iaften 10 Rdlr. fra Hjemmet, da det gaaer mig som alle de andre, at Lønningen ei kan slaae til. Det er da godt, at jeg kan skrive og saa erholde, hvad jeg forlanger.

18) Ved forposter o. lign. vil man almindeligvis ændre opstilling om natten dels for at hindre fjenden $i$ at udnytte den viden, han om dagen har skaffet sig om anbringelse af poster m. v., og dels for at modsvare de særlige krav, en bevogtning af terrainet kræver i mørke. - En sådan opstilling benævnes natstilling. 
$(31 / 1250)$

Jeg har i det henrundne Aar ikke seet mit inderlig elskede Hjem. Kun een Gang, paa Als, har jeg seet nogle af mine Kjære i Hjemmet, nemlig da Fader besøgte mig, kort før vi brøde op for at marschere til Slesvig.

Min Moder har to Gange været alvorlig og længe syg, og jeg har næsten ikke ventet, at hun levede. Men Herren være lovet, endnu lever hun, og jeg haaber ved mig selv, at jeg endnu skal see hende og glædes. Naar jeg tænker paa, hvor ofte jeg har ventet Brev hjemmefra for at see, hvordan hun havde det, bliver jeg underlig tilmode. Jeg har mangfoldige Gange i spændt Forventning aabnet Brevene, især i denne sidste langvarige Sygdom, hun har havt. O, maatte jeg i det næste Aar see hende og see dem alle i det kjære Hjem, maatte Krigen faae en glædelig Ende, hvilken Jubel vilde der ikke blive. Jeg kan næsten ikke taale at tænke derpaa. Gud i Himlen som seer og veed, hvad der tjener os alle og enhver især bedst, ham være Sagen anbefalet.

Jeg har i det henrundne Aar ikke været i Slag. Det har været Herrens Vilje.

I alle Farer som ellers, som allesteder, kan være nær, er jeg blevet bevaret. Jeg har slet ikke været syg $^{16}$ ), men har stadig kunnet passe min Dont.

Da jeg den 25. Juli saae mine Brødre at stride og stride haardt, var det mig rigtignok underligt at tænke paa, at jeg skulde ikke deeltage i Kampen. Jeg fulgte med, idet jeg sukkede til Herren, at han dog vilde give os Seier, og jeg kan sige, at hvis jeg skulde have deeltaget i Kampen, saa havde det ikke været mig tungt; thi jeg følte den Dag, at Kjærligheden til min Moder, Danmark, opflammede mig. Hvis ikke jeg havde været commanderet til hiin Dag at passe noget andet, hvis jeg havde selv undraget mig Kampen, da havde jeg nu været utrøstelig og

$\left.{ }^{19}\right)$ Hærens tab som følge af krigslæsioner var i treårskrigen mindre end tab p. g. af sygdom (især tyfus). 
vilde aldrig kunnet tænke paa mine Kammerater, men en ond Samvittighed vilde have fulgt mig overalt.

Og hermed slutter jeg min Dagbog for 1850 og haaber, at jeg ved en anden Gang [at] see den vil mindes disse mærkelige Dage og Herrens underlige Førelser.

Han være lovet, som i dette henrundne Aar har bevaret mig til Legeme og Sjæl. Han være lovet for sin store Naade".

\section{Efterskrift.}

Alt dette ligger nu hundrede år tilbage, og alene af den grund er meget fra hine tider gået i glemmebogen.

Ganske vist kender de fleste fra deres skoletid en del af de vigtigste begivenheder fra treårskrigen. Men det meste er efterhånden udvisket, dels fordi krigen i 1864 fik så langt mere gennemgribende betydning for landet, og dels fordi den almindelige udvikling siden dengang, ikke mindst i den sidste menneskealder, har været så voldsom, at den ganske har fået datidens begivenheder til at blegne.

Det vil derfor som slutning være rimeligt ganske kort her at trække hovedlinierne op for afslutningen af den første slesvigske krig.

Vi har allerede set, at slaget ved Isted ikke blev den store og afgørende sejr, det havde været muligt at opnå. Oprørshæren kom sig derfor ret hurtigt ovenpå nederlaget, bl. a. fordi den fik støtte syd fra. Den blev derfor i stand til at gå angrebsvis til værks, således som det skete ved Frederiksstad.

Fjendens storm på Frederiksstad mislykkedes, men han var stadig sådan stillet, at et fornyet angreb måtte ventes, såfremt en streng vinter gjorde Danevirkestillingens opbløäte forterrain farbar udenfor vejene.

Mens de to hære således stod afventende, fik krigen helt præg af rekognosceringer og patrouillevirksomhed, der førte til næsten daglige sammenstød.

Det er ikke godt at vide, hvorlænge denne tilstand kunne 
have vedvaret, men brat fik den ende. På årets sidste dag udkæmpedes felttogets sidste lille sammenstød ved Møhlhorst, og lidt efter lidt gled livet $i$ hertugdømmerne ind i normalt gænge.

Det var stormagtsindgriben, som havde forårsaget denne pludselige ændring.

Ved trusel om anvendelse af militær magt tvang den russiske czar Prøjsen til i det slesvigholstenske spørgsmål at indordne sig under den østrigske politik. Ved et forlig i november 1850 enedes de to tyske stormagter derpå om at bringe fjendtlighederne i hertugdømmerne til ophør.

Herved blev insurgenternes stilling ganske uholdbar, og i de første dage af januar 1851 blev oprørshæren trukket syd for Eideren, samtidig med at omfattende hjemsendelser påbegyndtes.

For vort vedkommende måtte de tre felttog stå som en sejr. Dette var berettiget for så vidt som krigen og dens gang var forløbet gunstig i militær henseende og derved fik stor betydning for det danske folks samhørighedsfølelse og selvtillid. Men sejren var ikke af et sådant omfang, at den kunne få virkelig politisk betydning, hvorfor den ikke bragte nogen løsning på det slesvigske spørgsmål.

Efter denne udredning virker det ikke overraskende, at Morten Nielsen allerede i marts 1851 kunne komme hjem.

For så vidt kunne vi slutte med dette, men der er dog fra hans sidste tjenestetid enkelte småtræk, som hører med til en fuldstændiggørelse af det foregående, hvorfor det vil være naturligt at tage disse småting med her.

Et par gange i januar besøgte Morten Nielsen præsten i Ulsby, pastor Mohr, som han kendte fra hjemmet. Pastor Mohr havde nu fået et kald i Sydslesvig, hvor han syntes godt om at være, „da han endnu ingen Fanatisme havde fundet“. - Også degnen i Ulsby var dansk. I en dagbog af langt senere dato er iøvrigt en bemærkning, der kunne tyde på, at pastor Mohr 
senere har forsøgt at overtale Morten til at søge et lærerkald på denne egn.

Om sine indtryk $\mathrm{i}$ forbindelse med demobiliseringen af den slesvigholstenske hær fortæller Morten Nielsen bl. a.:

\section{(21/1 51):}

Da vi marscherte tilbage fra Præsentation mødte vi nok en Hob permitterede Slesvigere af Insurgentarmeen, der blev transporterede af dansk Militair. De kom lidt slukørede. Vi derimod kom i tactfast Marsch med stolt Holdning forbi dem. Hvem skulde for kort siden have sagt dette. Ingen troede, at det saasnart skulde have blevet Forandring. Det var et underligt Øieblik, da jeg marscherede forbi disse permitterede, der for faa Dage siden vare vore Fjender.

De arme Slesvigs Indvaanere, de stod i Vinduer og Døre og skulde see deres Sønner komme hjem med uforrettet Sag.

Stemningen var meget nedtrykt, men nu kan de see og vil herefter faae at føle, hvad det er at gjøre Oprør.

$(22 / 151):$

..... De vare saa sikre i Begyndelsen, at vi nok skulde komme trekantet her ud af Byen, men de toge feil.

Blandt flere Smaating her ere passerede i disse Dage, vil jeg anføre en Historie, der passerede igaar aftes, da de første Insurgenter kom ind. Pigerne kastede alt af Hænderne og løb. Tine i sin Glæde og i sin \#Ergrelse, om jeg saa kan udtrykke mig, løb hen og tog fat $i$ den første den Bedstes Haand og begyndte at tale til ham om, hvordan han havde havt det osv., som han besvarte paa Plattydsk, og Samtalen gik ret gemytligt. Det var en Slesviger af vores 13. Batl., der kunde tale tydsk, og hun tog feil af ham, da han gik ved Siden for at eskortere Insurgenterne. En af disse bliver det vaer og siger til hende:

"Das ist ja ein Däne", Hu, Hu — sagde hun og fløi paa Hovedet $i$ Rendestenen af bare Forskrækkelse......

Siden er hun ikke kommet længer end i Gadedøren. 
(25/1 51):

Den største Flok, som kom i Eftermiddag, var fra 13. Insurgentbataillon. Hänchens Broder var der med. Hun drog lige ud iblandt dem for at hilse paa ham.

Saasnart en Flok ankommer, saa kaste de alt af Hænderne og løbe. Der undslipper dem da mangt et Ord, som er tungt at høre, naar de see dem komme.

Tine sagde iaftes til mig, at hun havde talt med En, der hilste meget venligt og sagde "Godaften Søster", hvorpaa han spurgte: „Er du endnu ægte (tydsk)“. „Javel Broder“, svarte hun.

Det er svært at høre saadant, og det kan ikke andet end gjøre et ubehageligt Indtryk.

Forresten troe jeg, at de fleste af [de] Hjemvendende ere fornøiede af det Hele. Iaften havde endeel været samlede i Holsteinisches Haus og har der raabt Hurra for Frederik den Syvende.

Den lavere Klasse har ingenlunde været for Oprøret, og derom vidner bedst dette, at de nu uden videre lader Soldaterne vende hjem igjennem vores Kjæde. Det er kun de Store, som have ledet Oprøret, at der er Skyld i det Hele. Hvorledes disses Samvittighed vil være, det er ikke godt at vide, især naar de betænke, hvormegen Ulykke og Sorg, de have bragt over Landet."

Vor hær blev i januar-februar 1851 forlagt til garnisonerne, dog blev en mindre styrke, især reserve- og forstærkningsbatailloner i hertugdømmerne.

Til denne sidste styrke hørte også 3. reservejægerkorps, som i begyndelsen af februar blev forlagt til Tønder.

$\mathrm{Da}$ der var stor mangel på egnede underofficerer til at varetage de mange administrative forretninger ved kompagnierne $i$ forbindelse med hjemsendelsen, indvilgede Morten Nielsen i at blive for en kortere tid. 
Den første aften efter sin hjemsendelse nåede han Bæk i Nustrup sogn, kaptajnen havde ladet trainkusken køre. I Bæk tog han ind til sin moders morbroder, der i sin tid var flyttet fra Fyen til Sønderjylland.

Om sine tanker ved hjemsendelsen skrev han samme aften følgende:

„Imorges førend jeg endnu var staaet op, sendte Capitainen Bud til mig, om jeg vilde møde tillige med Compagniet udenfor Seminariebygningen $\mathrm{Kl} .8$.

$\mathrm{Da}$ vi der vare samlede, marschertes ind i Fægtesalen, hvor Compagniet opstilledes. Capitainen lod skuldre og kaldte mig derpaa frem foran Compagniet, og jeg mærkede da, hvorfor vi vare samlede.

Han holdt en Tale, der var temmelig lang og begyndte med, at Compagniet var samlet i Anledning af, at en agtet Underofficer skulde forlade os, hvorpaae han saae til mig. Saa nøie kan jeg ikke kuske, hvád han sagde, men jeg maae tilstaae, at han gav mig et Lov, som jeg aldrig har dromt om.

Til Compagniet sagde han "- han har som kun Faa rogtet den Post, hvori han [har] været sat, jeg har betragtet ham mere som Ven end som Undergiven, og ikke alene er det min særdeles Tillid, han har, men det er Oberstlieutenantens og enhver Foresats. Hans Undergivne har villigt lydt hans Befalinger, thi de har havt Erefrygt for ham. Det er ikke alene hans Retskaffenhed og hans Flid, men hans Forhold har $i$ alle Henseender været rosværdigt, og jeg tør sige, der er ikke en Underofficer i hele den danske Armee, der har gjort sin Pligt bedre end han."

Idet han sagde disse sidste Ord, blev han synlig rørt og kunde næppe holde Taaren tilbage. Han vendte sig derpaa om til mig og rakte mig Haanden og sagde: „Tak skal Du have min kjære Elleruplund, jeg ønsker, det maae [gaa] Dig vel, hvor Du kommer hen i Verden, jeg takker Dig.“ 
Jeg tilstaaer, at jeg ikke har oplevet en saadan Stund som denne Afskedens i den Tid, jeg har været Soldat. Jeg blev overvældet af mine Følelser og vidste snart hverken ud eller ind.

Taus og tankefuld gik jeg ned ad Gaden, og jeg var baade glad og sorrigfuld. Min kjære Capitain stod mig bestandig i Tanke. Der randt meget ind fra de sidste Aar, af hvad der har været os til fælleds Glæde eller til fælleds Sorg.

Mine Kammerater saae paa mig og lykønskede mig, thi de kunde see, at jeg havde een af de sjeldnere Dage, men det kunde ikke rigtig hjælpe. Jeg var eengang bragt ud af Fatningen, og jeg kunde ikke faae den igjen." 